\title{
The Influence of Dualism and Pragmatism on Physical Education
}

\author{
Martin Kudláček
}

Palacky University in Olomouc, Czech Republic

ABSTRACT

\begin{abstract}
Physical education is an area in which most professionals focus only on the body and its needs. Most PE teachers do not believe that having an understanding of philosophy is important in order to be a good teacher. One might ask why the physical educators think this. Looking at the history of philosophy we might find the answer within philosophy itself. Physical education is an unquestionable part of the school curriculum, but it does not have the same value as other subjects. The importance of PE is underestimated as school administrators stress the importance of academic subjects. The reason why physical education is so strongly separated from academic disciplines is because of its roots in ancient Greek times, when the soul was separated from the body. Medieval scholars stressed the importance of soul and cursed body as the nest of sins. From then on we have had dualism, a term which is widely adopted by western society. Dualism is so deep in us that we do not realize its impact any more. Other strong educational influence came from great thinkers such as: Comenius (1592-1670), Rousseau (1712-1778) and Dewey (1859-1952). Particularly Dewey's influence on American education, society, psychology, philosophy and way of life is significant. An importance of the experience is valued by Pragmatism. Pragmatists believe that the curriculum should be focused on the child and not on facts, they remind us about the role of education in society, and about the realization of the deep roots of division of our bodily and mental functions. The opportunities offered by the pragmatist's approach to education can help us to improve U.S. education, particularly physical education, and thus to use this to improve the state of American society.
\end{abstract}

KEYWORDS movement, physical activity, philosophy, framework

\section{Dualism in modern society}

\section{Early foundations}

Modern science strictly keeps boundaries between material and non-material views of the world. There exist social sciences and physical sciences, these are unfortunately strictly divided into those that study the human body and those that care about mind or soul. Many researchers thus cannot see the influence of their work on society, and many people who are interested in the human mind underestimate the importance of physical education and physical needs as part of a healthy life. The first ideas about such duality were born in ancient Greece and are connected with famous names such as Plato (427-347 B.C.) and Aristotle (384-322 B.C.). Runes (1959) states that Aristotle influenced 
Greek philosophy with his belief about two dichotomies: matter and form. Dewey (1969, p.114 ) says: "It was the 'master of those who know' that said that the soul was the perfect realization or expression of a natural body, and at the same time, not the product of body, but its very life, its essence, its truth and reality." Aristotle (1933, p.43) defines ideas in Plato's words: "These entities he called 'Ideas', and held that all sensible things are named after them... for the plurality of things which bear the same name as the Forms exist by participation in them". Old Greeks were aware of the need for a balance of body and mental needs. This philosophy is acknowledged by the term Kalokaghatia, which means the beauty of body and soul. In fact physical culture played an extremely important role in Greek society, and modern scientists, teachers, politicians and common people respect the idea of the Olympic Games. The history of the Games is more then 2000 years old. This philosophy of balanced life and approach was almost completely destroyed in early and medieval Christianity.

\section{Medieval times}

Early Christians did not believe in the importance of the body, focusing on the nourishing of the soul. They believed that the body was just the centre for human sins and therefore of no importance. Another suggested reason for rejecting the values of physical culture was the Roman Empire. Romans adopted Greek cultural heritage, and although they banned the Olympic Games, they were engaged in activities of physical culture. Their military training required strong and fit soldiers, they had very modern spa and well-known gladiatorial games. The early Christians saw Roman abuse of a physical culture, they were often arrested, and had to fight with Gladiators or savage animals. We know that physical culture was very underestimated during the Christian expansion in Europe. Everything physical was considered sinful and not proper activity. Apart from the military training, there was no interest in any kind of exercise. This era is often cited as a dark age of physical culture.

\section{Dualism and modern society}

Dualism did indeed influence all modern sciences, western philosophies and all daily matters of our lives. The ancient philosophers also laid down the basis for physical sciences. It is unfortunate that their ideas were misunderstood. For example, modern medicine is really good in the matter of real physics, it has sophisticated methods of surgery and whole armies of drugs that can be prescribed for almost any symptom. Western physicians do not look at the person as whole, they are not concerned about his psychological, social or spiritual life, they do not try to understand peoples lives, they just look at symptoms and prescribe proper drugs. Physical education at schools is also influenced by dualism. We focus mostly on physical needs and often neglect other parts of the student. In university, kinesiology preparation courses are split up into its practical (physical) and theoretical (mental) foundations. At schools, academic subjects are highly preferred and physical education is often just an after-thought. It is hard to believe that all of this could be caused just be separating ideas of matter or body from soul. This is how our society evolved. On the other hand this dualism is not only passively accepted by philosophers, some of them did decide to challenge this belief. Lovejoy (1955) writes: "The last quarter of the century, it may fairly confidently be predicted, will have for future historians of philosophy a distinctive interest and instructiveness as the Age of the Great Revolt against dualism..." (p. 1). Now it is in our hands, we should consider how dualism influenced every one of us. Do we prefer some part of human substance, or are we equally looking at both the body and the mind? We can argue that our lives have more than just two spheres, there is physical, social, psychological, and spiritual. Dualism is still here and we should try to unite our needs and advocate the idea of Kalokaghatia. 


\section{The role of pragmatic philosophy}

\section{Pragmatism and its founders}

Americans are pragmatic people, they do not wonder about deep philosophical questions, instead they simply act. The U.S. is probably the most outcome-oriented country in the world. People are used to doing what works for them. Unfortunately the measure of effectiveness is mostly cost, and to be successful in America you need to be rich. In order to figure out the real meaning of the word Pragmatism we need to look at the founders of this philosophical school. Pragmatism was found in America in the $19^{\text {th }}$ century by Charles Sanders Pierce (1839-1914). Pierce, who introduced pragmatism in an article that appeared in Popular Science Monthly in 1887, attacked the problem of dualism of mind and matter (Ozmon 1984), and was never given enough recognition. Pierce had taught at Harvard during 1864-1865 and 1869-1870 and at Johns Hopkins during 1879-1884, but he never became a professor (Runes 1959). William James (1842-1910) is considered by many as the founder of pragmatism. Ayer describe him (James 1978) as the man who, as professor at Harvard, made pragmatism available and advocated the pragmatic importance of experience. He earned a medical degree at Harvard and returned there in 1872 as an instructor of physiology. In 1876 he became a lecturer in psychology and in 1880 became a professor of philosophy (Ayer in: James, 1978). James never tried to get credit for the founding of pragmatism.

James (1978, p.28) on pragmatism:

"The term is derived from the Greek word, meaning action, from which our words 'practice' and 'practical' come. It was introduced into philosophy by Mr. Charles Pierce in 1878. In an popular article entitled 'How to Make Our Ideas Clear'.... Mr. Pierce, after pointing out that our beliefs are really rules for action, said that, to develop a thought's meaning, we need only determine what conduct it is fitted to produce: that conduct is for its sole significance".

Childs (1956, p. 1) remind us about an important fact. "The outstanding feature of this philosophy is its empirical character. It accepts ordinary human experience as the ultimate source and test of all knowledge and value". The account of the founders of pragmatism would not be complete without mentioning "the reformer of American education", John Dewey (1859-1952). Dewey applied principles of experience to education. He was able to appreciate the role of the child and focus all education on the student. In his work he addressed teachers and administrators, advocating the importance of experience in the learning process. Dewey taught philosophy at the University of Minnesota in 1888-1889, the University of Michigan in 1889-1894 and the University of Chicago in 1894-1904.

\section{Pragmatic America}

One might ask the question: Why did pragmatism start in America? Childs (1956) claims that the American society still remembered its struggle and "real experience" with the settling of the frontier. The general tendency of pioneers was that the human can master the circumstances of life. The mobility of Americans and function orientation of new laws, governments and social institutions was obvious. Pioneers were constantly creating new institutions under which they lived. In the 1880s the American society was very future-oriented, thus there were no strong ties with "the old continental" history or systems of authority. People had to think about the future, not the past. The frontier experience had also taught people to judge the value of an idea by its functioning. Like people, ideass that were successful were respected. 


\section{Early foundation of educational pragmatism}

Johann Amos Comenius (1592-1670). While celebrating Dewey's influence on education, it would be unfair not to mention the great thinkers whose ideas were somewhat reconcilable with a pragmatic view of education. Johann Amos Comenius was the first democrat among the Christian educational philosophers (Runes 1959). In Europe he is often cited as the great "teacher of the nations". He was a humanistic thinker who believed that educated people would be less likely to have wars. He fled from Bohemia (in the Czech republic) in 1628 when the country lost its liberty and was occupied by the Habsburg emperor. He was never allowed to return home, but he never lost confidence in the rational mind and human progress. Comenius was aware of the needs of children and opposed traditional forms of learning by memorizing. He established educational principles that are still valid today. These principles are described in very poetic way in his book The Great Didactic. For example: Nature observes suitable time (the principle of appropriate age). Nature makes no leap, but proceeds step by step (the principle of continuous learning). Nature chooses a fit subject to act upon, or first submits one to a suitable treatment in order to make it fit (the principle of an individual approach). (Comenius 1923, pp. 111-123) With the general program advocated by Comenius we can understand how advanced his thinking was:

"2. We promise, then, such a system of education that

All the young shall be educated (except those to whom God has denied understanding).

And in all those subjects which are able to make a man wise, virtuous, and pious.

That the process of education, being preparation for life, shall be completed before maturity is reached.

That this education shall be conducted without blows, rigour, or compulsion, as gently and pleasantly as possible, and in the most natural manner (just as a living body increases its size without any straining or forcible extension of the limbs; since if food, care, and exercise are properly supplied, the body grows and becomes strong, gradually, imperceptibly, and of its own accord. In the same way I maintain that nutriment, care, and exercise, prudently supplied to the mind, lead it naturally to wisdom, virtue, and piety" (Comenius, 1923, p. 81).

As well as pragmatists Comenius (1923) stressed an importance of education through experience. "Experience is deceptive in order that our attention may be excited, and that we may feel the necessity of penetrating to the essential nature of things" (p. 102). Comenius also considered physical education as an important part of school. Rice \& Hutchinson (1952, p. 83) describe his approach as: "As for physical education Comenius says, gymnastics and games, running, jumping, wrestling, ball, playing, and ninepins are to be encouraged. The teacher is to take pupils on long hikes both for recreation and study. He, like Locke and others, believes in physical discipline and simple food. He suggests that the day is divided into three parts, eight hours for sleep, eight for work, and eight for nourishment, recreation, and physical development". In the work of Comenius we can clearly see his pragmatic ideas of education. We should try to fulfil his ideas of natural, age and individual appropriate education, where physical education is as important as academic subjects.

Jean Jacques Rousseau (1712-1778). Rousseau focused his work on natural education. He believed in fact that all humans are equal and free. He was truly disappointed by what civilization had done and he advocated a return to nature. Rousseau claimed that civilization is a cause of unhappiness. We can sense how strict his views were in the opening of his book Emilius and Sophia. "All things are good as their Creator made them, but every thing degenerates in the hands of man.... His very offspring must be trained up for him, like a horse in menage, and be taught to grow, after his own fancy, like a tree in his garden" (p. 1). Rice \& Hutchinson (1952) gathered some of Rousseau's views 
of the importance of exercise and physical activities. "If you would cultivate the intelligence of your pupil, cultivate the power which it is to govern. Give his body continual exercise; make him robust and sound in order to make him wise and reasonable; let him work and move about and run and shout and be continually in motion...." (p. 87). All educators should give him credit for such thinking. If we could travel in space and time we could see very similar ideas in the Far East. Yoga was created as an exercise to support the thinking mind, and monks of the Shaolin temple created their martial art in order to strengthen their body for meditation. Ancient Greeks respected an idea of Kalokaghatia, the unity of strong mind and body. What is our approach to this philosophical problem? Western societies still have not discovered a close relationship between mind and body. This was a lesson of the old educators. Can we learn something from it?

\section{Dewey's attribute to education.}

John Dewey can be called a modern Rousseau or Comenius. He had seen the inadequate state of education and the beginnings of pragmatism. The conditions of schools in his time were not very democratic, open and creative. Teaching was fact-oriented and teachers were not aware of the psychological conditions of their students. Dewey had introduced psychological principles of learning, which were not too far from principles of Comenius, so we see how history repeats itself. It is very interesting to compare so-called traditional teaching styles, that are mostly focused on memorizing facts, and creative education, that is more process-oriented, encourages students independence, creativity and individual development. Dewey suggested combining classes that were closely related, creating a curriculum from study cores that were focused for example on exploration. Ozmon \& Craver (1984, p. 115) say: "One could hardly study exploration without becoming involved in both social studies and the sciences". The quality of teachers is often discussed in modern society. Dewey (1904) claims that it is not the amount of facts that teachers must know, it is a misunderstanding of the consequences of teaching and the relationship between different classes that causes this deficiency. "The trouble was that they did not consider the other factor in creating an experience; namely the powers and purposes of those taught" (Dewey 1938, p. 44). Dewey criticized the older methods for using passivity and receptivity and requiring silence as a precondition for good education. Children had to sit still, learn facts and not be disruptive. Dewey advocates his ideas in the book The school and the Child, where he states: "Again, the child's life is an integral, a total one. He passes quickly and readily from one topic to another, as from one spot to another, but is not conscious of a transition or break....The things that occupy him are held together by the unity of the personal and social interests which his life carries along" (p. 19). One might ask, what we have done to our children. Schools have adopted the old, traditional ways of teaching, but have not considered the new demands of a rapidly growing body of knowledge. The question then would be when teachers realize that students cannot know everything. Probably the most important thing is to awaken an interest in children, a little spark that can instigate fire, a fire of desire to learn to understand. Dewey like Comenius stresses the importance of students' interest and experience. Dewey (1938, p. 113) clearly states: "Education in order to accomplish its ends both for the individual learner and for society must be based upon experience which is always the actual life-experience of some individual". Teachers and parents wonder why students do not like school, why are they not studying and why are they not motivated. Dewey might have an answer for us. School is not giving them enough experience, they feel detached from the real world. Students do not understand why they should know certain facts.

"On the other hand, if an experience arouses curiosity, strengthens initiative, and sets up desires and purposes that are sufficiently intense to carry a person over dead places in the future, continuity works in a very different way. Every experience is a moving force. Its value can be judged only on the ground of what it moves toward and into" (Dewey 1938, p. 31). 


\section{Education and society.}

"Pragmatists argue that we need to make persons aware of consequences of their actions so they may guide their actions more intelligently" (Ozmon \& Craver 1984, p. 114). Society is undoubtedly a group of individuals whose actions directly or non-directly influence the lives of others. American society is considered to be very complex, because of tremendous socioeconomic, cultural and gender differences. Citizens that are unaware of the consequences of their actions, behavior, and habits, cause many problems for themselves as well as others. Do schools assume the authority to teach students to be responsible for their actions? We can ask this in a different way: Does American society care about teaching children to learn about the consequences of their actions? An individual responsibility of each citizen is the magic of democracy, which makes it so special. One might claim that money is the magic, and the truth is that money means a lot in American society. Childs (1956, p. 291) states: "democracy, like swimming, requires practice as well as theory, the school should be so organized that it will be as perfect an embodiment of the democratic ideal as we are able to achieve and thus equipped to provide the youth with actual experience in democratic living".

Physical education can play an extremely important role in shaping of students' character.

By its nature PE is very emotional and thus students often display their behavior, which can be inappropriate and non-democratic, with a negative impact on other students. All students can learn this way to realize an importance of so-called fair play and respect for others. Unfortunately sport, which is closely connected with physical education, has lost its originally pure motives and is frequently quite immoral. Outdoor education realizes the strength of experience and the power of nature and with these provides unforgettable experiences which truly influence students' lives. The fact is that an experience of overcoming personal challenges is motivating for future life. Such an experience creates selfconfidence, a quality which is extremely important for responsible living. These programs are often working with youth at risk of turning to crime. This approach is quite successful and is applicable to all people. Schools often underestimate the importance of the experience of success in education. In the lifetime physical activities the positive experience is a key factor. A person with successful and enjoyable experience with physical activities will more likely participate in such activities in future leisure time. Experts are aware of the importance of sport in leisure time, but they underestimate or do not consider the major role of experience with these activities in childhood.

\section{Pragmatism and students with disabilities.}

Pragmatists focus their teaching attention on children, rather than the curriculum. It is a very important fact that supports an individualized approach to students with disabilities. IDEA guarantees an IEP (individualized education program) for each child. In such programs the curriculum is modified or created for an individual student. Sherrill (1985, p. 267) states: "Pragmatists conceptualize the gymnasium as a microcosm of real life and thus accept handicapped students into their classes in the same way and to the same extent that they accept them in society". It is the significance of the experience that is so important for students with disabilities and their non-disabled peers. Integrated into regular schools, students with disabilities experience being in "normal" society, a place where they belong and which they enter after school graduation. It is the teachers' responsibility to make this integration successful. Keeping in mind the tremendous importance of experience, we can conclude that having experience with peers with disabilities will stay with them for the rest of their lives. This experience is multiple stimulus for the personal growth and creates the democratic environment. 


\section{Conclusion}

In this paper we have explored how philosophy can significantly influence whole society, education and indeed physical education as well. Not caring about philosophy is rather dualistic, and by acknowledging this fact we are starting to deal with philosophy. During history there have been many great thinkers who shifted western civilization towards its current state. Philosophy used to be a major discipline of higher education, and it should be applied in every discipline. There is no single action that would not influence society, and we should understand consequences of our actions. Great educators like Comenius, Rousseau and Dewey did their work to improve the status of education. We need to learn from them and apply their knowledge to our work.

\section{REFERENCES}

Aristotles. (1933). The Metaphysics. Cambridge, MA: Harvard University Press.

Childs, J. L. (1956). American pragmatism and education. New York: Henry Holt and Comp

Comenius, J. A. (1923). Great didactics. London: A. \& C. Black, LTD.

Dewey, J. (1904). The educational situation. Chicago, IL: The University of Chicago Press.

Dewey, J. (1906). The school and the child. London: Blackie and Son Limited.

Dewey, J. (1938). Experience and education. New York: The Macmillan Company.

Dewey, J. (1969). The early works, 1882-1898. Amsterdam, IL: Carbondale and Edwardsville.

Hackensmith, C.W (1966). History of physical education. New York: Harper \& Row Publishers.

James, W. (1978). Pragmatism and the meaning of truth. Cambridge, MA: Harvard University Press.

Lovejoy, A. O. (1955). The revolt against dualism. La Salle, IL: The Open Court Publishing Company.

Ozmon, H. \& Craver, S. (1984). Philospophical founding education. Columbus, OH: Merrill Publishing Company.

Rice, E. A., \& Hutchinson, J. L. (1952). A brief history of physical education. New York: A. S. Barnes and Company.

Rousseau, J. J. (1767). Emilius and Sophia. (Vol. 1). London: T. Becket \& P. A. de Hondt.

Runes, D. D. (1959). Pictorial history of philosophy. New York: Philosophical Library.

Sherrill, C. (1985). Integration of handicapped students: Philosophical Roots in Pragmatism, Idealism, and Realism. Adapted Physical Activity Quarterly, 2, $264-272$. 